\title{
Changes in vegetation and marine environments in the eastern Mediterranean (Rhodes, Greece) during the Early and Middle Pleistocene
}

\author{
SÉBASTIEN JOANNIN ${ }^{1}$, JEAN-JACQUES CORNÉE ${ }^{1}$, PIERRE MOISSETTE ${ }^{1}$, JEAN-PIERRE SUC ${ }^{1}$, \\ EFTERPI KOSKERIDOU ${ }^{2}$, CHRISTOPHE LÉCUYER ${ }^{1,3}$, CÉDRIC BUISINE ${ }^{1}$, KATARINA KOULI ${ }^{2}$ \& \\ SERGE FERRY ${ }^{1}$ \\ ${ }^{1}$ UMR 5125 PEPS, Université Lyon 1, Campus de La Doua, Bt. Géode, 69622 Villeurbanne Cedex, France \\ (e-mail: sebastien.joannin@univ-lyon1.fr) \\ ${ }^{2}$ Department of Historical Geology-Paleontology, University of Athens, Panepistimiopolis, Zografou, \\ 15784 Athens, Greece \\ ${ }^{3}$ Institut Universitaire de France, Paris, France
}

\begin{abstract}
Pollen records, marine faunal associations and stable isotope compositions of sediments from Rhodes, Greece, have been determined to track environmental changes in the eastern Mediterranean during the Early and Middle Pleistocene. A detailed chronostratigraphic curve, based on magnetostratigraphic data, was obtained by correlating pollen spectra with the Mediterranean oxygen isotopic curve of Ocean Drilling Program Site 975. Five sedimentary sequences that correspond to marine oxygen isotope stage (MIS) 31-27 and to MIS 20-17 have been investigated in the confined Tsampika microbasin. High-amplitude Pinus variations confirm glacio-eustatic changes deduced from changes in marine faunal associations and sedimentary depositional environments. Reflecting climatic cycles identified in the marine carbonate oxygen isotope record, eight vegetation successions (characterized by the dominance first of mesothermic elements, then of mid- and high-altitude elements with Pinus, and ending with maxima in herb and steppe elements) have been documented. Most of them were probably driven by changes in insolation occurring in high northern latitudes (obliquity impact) during the late Early Pleistocene and early Middle Pleistocene.
\end{abstract}

Since the Late Pliocene (i.e. about 2.6 Ma), the Earth has undergone major environmental perturbations that were triggered by climate dynamics expressed in terms of changes in mean temperature, seasonality, humidity and ice-cap extent. Ice volume and marine temperature variations are notably recorded in the oxygen isotope composition of foraminifer shells (Lisiecki \& Raymo 2005). Variations in ice volume are related to glacial and interglacial periods (i.e. climatic cycles; Ruddiman 2003; Berger $\&$ Loutre 2004). Climate is primarily forced by orbital parameters, these being eccentricity (100 ka period, as a precession modulator, Maslin \& Ridgwell 2005), obliquity (41 ka period), and precession (20 ka period). The response of the climate system to obliquity or precession forcing affects the duration of the climatic cycles (Maslin \& Ridgwell 2005). During the Late Pliocene and Early Pleistocene, the climate system dominantly responded to obliquity, resulting in $41 \mathrm{ka}$ climatic cycles (Pisias \& Moore 1981; Kroon et al. 1998; Ruddiman 2003). However, from the Middle Pleistocene (at about $0.9-0.8 \mathrm{Ma}$ ) to the present day, the climate system mainly responded to a combination of eccentricity and precession (100 ka cycles; Von Grafenstein et al. 1999; Ruddiman 2003). Mudelsee \& Stattegger (1997) and Maslin \& Ridgwell (2005) placed the beginning of the $100 \mathrm{ka}$ cycles at $0.620 \mathrm{Ma}$. Earth's climate experienced a global cooling during this period (Ruddiman 2003). The change of dominant frequency response of the climate from obliquity to precession is known as the Middle Pleistocene Revolution (MPR; Maslin \& Ridgwell 2005).

During this time of intensive climate change, the subduction of the African plate under the Aegean plate resulted in the formation of the eastern Hellenic forearc (Vanney \& Genneseaux
1985). The Greek island of Rhodes (Fig. 1) belongs to this arc and was separated from Turkey during the Early Pliocene (Meulenkamp et al. 1972; Ten Veen \& Kleinspehn 2002). To the east is located the deep Rhodes basin, which has been interpreted as a post-Miocene subduction-related trench (Woodside et al. 2000).

The modern vegetation of Rhodes is inherited from the Asian subtropical vegetation of the Late Pliocene and Pleistocene. The influence of climatic cycles on vegetation during the Pliocene and Early Pleistocene was investigated in the Mediterranean region by analysing pollen from continental and marine sediments (Suc \& Zagwijn 1983; Suc 1984; Combourieu-Nebout \& Vergnaud-Grazzini 1991; Russo Ermolli 1994, 1999; RossignolStrick \& Paterne 1999; Subally et al. 1999). However, most of the studies dealing with vegetation changes of the Early-Middle Pleistocene transition have been conducted in Italy (Ravazzi \& Rossignol-Strick 1995; Capraro et al. 2005; Ravazzi et al. 2005). Furthermore, in Greece, Wijmstra \& Smit (1976), Okuda et al. (2002) and Tzedakis et al. (2003) provided detailed information on the distribution of the European and Mediterranean taxa during the last $600 \mathrm{ka}$. The eastern Mediterranean region was considered a refugium during this period (Svenning 2003). Understanding the Pleistocene vegetation changes in the eastern Mediterranean therefore requires the study of pollen from sediments older than $600 \mathrm{ka}$, when Antarctic ice core climatic records are not available (EPICA Community Members 2004).

This study is based on the pollen analysis of the Tsampika composite section belonging to the Ladiko-Tsampika Formation and dated as Early and Middle Pleistocene by Cornée et al. (2006). The goal of this study is to refine the chronology of the 


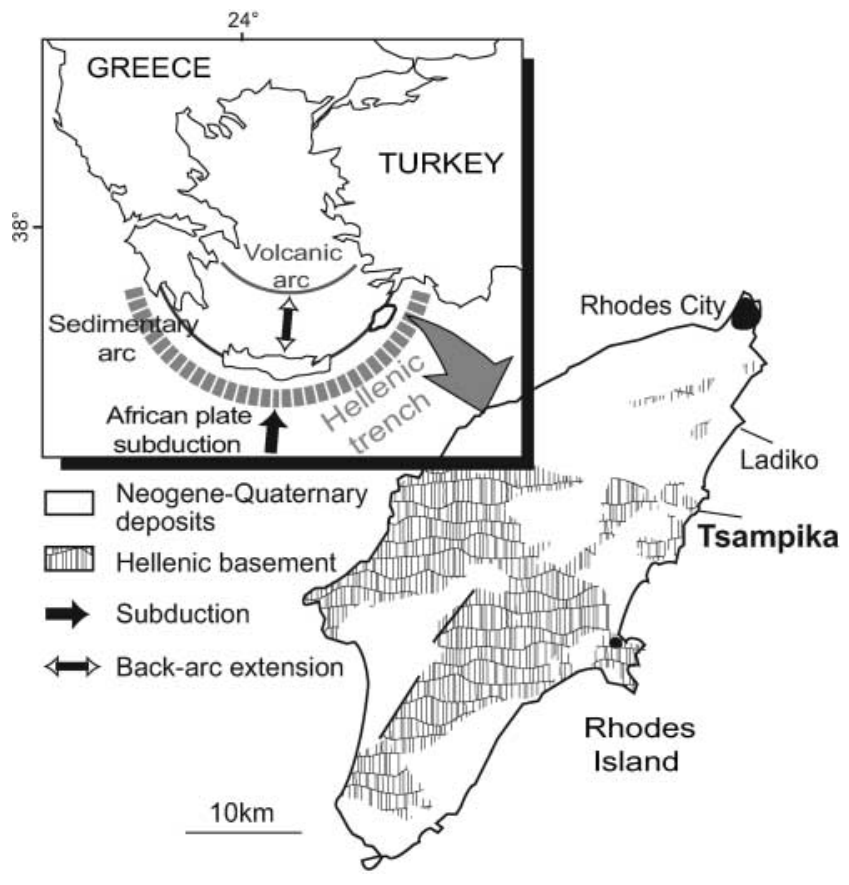

Fig. 1. Simplified geological map of Rhodes. Inset shows the general tectonic context of the eastern Mediterranean.

various sedimentary-climatic sequences by correlating our pollen spectra with marine oxygen isotope stages (MIS) derived from the Mediterranean oxygen isotope curve of De Kaenel et al. (1999).

The Early and Middle Pleistocene vegetation successions of Rhodes will be analysed through interglacial-glacial alternations to improve understanding of the phytogeographical evolution of the Mediterranean since the Pliocene. More specifically, we will examine how vegetation reacted to changes in the climate frequency response to orbital parameters (Magri \& Tzedakis 2000) at 41 ka cycles (Pisias \& Moore 1981; Kroon et al. 1998; Ruddiman 2003) and $100 \mathrm{ka}$ cycles (Mudelsee \& Stattegger 1997; Maslin \& Ridgwell 2005).

Oxygen isotope measurements of mollusc shells from the semi-enclosed Tsampika microbasin will be used to discuss seawater temperatures in relation to interglacial-glacial stages.

\section{Geological setting}

The Late Pliocene-Pleistocene deposits of Rhodes were unconformably deposited on the Aegean Chain (Mutti et al. 1970). Their general stratigraphic and sedimentological features were elucidated by Mutti et al. (1970), Meulenkamp et al. (1972) and Hanken et al. (1996). Cornée et al. (2006) investigated these deposits on the basis of field studies, sedimentology, bio- and magnetostratigraphy, palaeoecology and palynology. Those workers defined three formations separated by major erosional unconformities (Fig. 2a): the Late Pliocene to Early Pleistocene Rhodes Formation, the Early-Middle Pleistocene Ladiko-Tsampika Formation, and the Late Pleistocene Lindos-Acropolis Formation. The present work focuses on the Ladiko-Tsampika Formation, which was deposited between around 1.3-1.2 Ma and 0.3 Ma (Cornée et al. 2006).

The studied sections are located in Tsampika Bay (Fig. 2b). The siliciclastic deposits are about $160 \mathrm{~m}$ thick and organized in nine sedimentary sequences (TS1-TS9), which infilled an erosional palaeovalley (Cornée et al. 2006). Sequence TS1 consists of fluvial deposits grading upward into marine shoreface strata and then into deltaic littoral and low-salinity facies. Above are eight retrogradational-progradational sequences composed of continental to marine conglomerates, marine sandstones and monotonous offshore marine greenish silty clays. These sequences were interpreted as the result of decametric sea-level changes related to glacial-interglacial episodes. Variations in abundance of Pinus grains and changes in the 'pollen index' (mesothermic and mid- to high-altitude elements divided by herbaceous elements) were also correlated with climatic fluctuations. A restricted depositional environment, probably associated with the partly enclosed character of the embayment (Fig. 2c), was identified throughout the formation (Cornée et al. 2006). An abrupt synsedimentary tectonic episode occurred at the end of the deposition of sequence TS4, which is at present dismembered. The current study focuses on sequences TS1-TS3 and TS5-TS6 (Fig. 2c), as the other sequences do not allow full sampling.

\section{Modern climate and phytogeography}

Vegetation is generally organized into altitudinal vegetation belts corresponding to latitudinal zones (Ozenda 1975). This study focused on a small island with low elevations $(600 \mathrm{~m}$ at maximum), and so the pollen record is expected to be very sensitive to expansions or contractions of the vegetation belts, which can result from tectonic vertical motions or global climate changes.

The present-day climate of Rhodes is influenced by its relatively southern location, which induces higher temperatures compared with the cooler climate of western and central Europe. The mean annual temperature is about $19{ }^{\circ} \mathrm{C}$, and the annual precipitation about $893 \mathrm{~mm} \mathrm{a}^{-1}$ at Paradissi Station $\left(36^{\circ} 4^{\prime} \mathrm{N}\right.$; $28^{\circ} 08^{\prime} \mathrm{E}$; using LocClim 1.0.; FAO 2002). Because of the low elevation of the island, only two vegetation belts occur (Quézel \& Barbero 1985; Quézel \& Médail 2003): (1) the thermomediterranean belt, composed of Ceratonia siliqua, Pistacia lentiscus, Myrtus communis and Olea europaea subsp. silvestris in the eastern part of the island; with Pinus brutia and Cupressus sempervirens higher and in the western part of the island; (2) the mesomediterranean belt, found in the highest parts of Rhodes, which is also composed of Pinus brutia and Cupressus sempervirens.

Both vegetation belts also occur at low elevation in the coastal areas of western Turkey. However, with increasing elevation other belts are identified: the supramediterranean belt (Quercus coccifera, deciduous Quercus), the mountainous-Mediterranean belt (Cedrus libani, Taurus Mountain) and the Anatolian steppes on the high plateaux (Artemisia fragrans mainly). Pinus brutia and Cupressus sempervirens can live up to an altitude of $1700 \mathrm{~m}$. The Cedrus belt is located there between 1400 and $2000 \mathrm{~m}$ (with rainfall 1000-2000 $\mathrm{mm} \mathrm{a}^{-1}$; Quézel 1998).

\section{Materials and methods}

\section{Pollen}

A total of 116 samples were collected in sequences TS1-TS3 and TS5TS8 (Fig. 2b). The sampling interval in clayey sediments was $c .1 \mathrm{~m}$. Samples were processed using a standard method adapted from Cour (1974). $\mathrm{HCl}$ and $\mathrm{HF}$ treatments were followed by heavy liquid separation $\left(\mathrm{ZnCl}_{2}\right)$ and sieving of the residue between 160 and $10 \mu \mathrm{m}$. Eighty-seven samples provided enough pollen for analysis and 150 pollen grains, in 


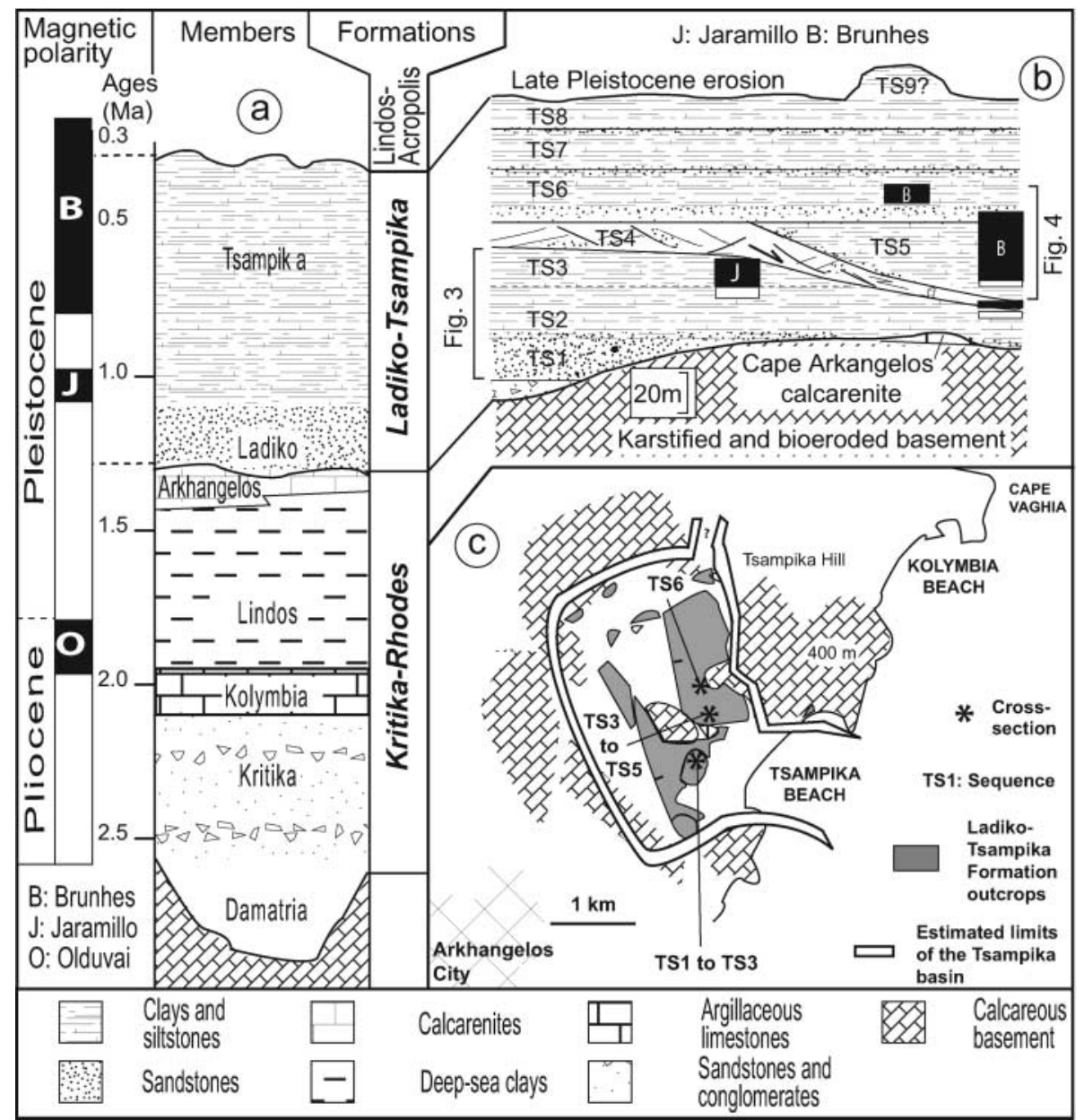

Fig. 2. (a) Chronostratigraphy of the PlioPleistocene deposits at Rhodes. (b) Sedimentary organization. (c) Tsampika basin spatial configuration. (b) and (c) adapted from Cornée et al. (2006). addition to those of Pinus, were counted and a minimum of 20 taxa identified in each sample. Thus about 32500 pollen grains were counted in the whole section.

Pollen grains in coastal marine terrigenous deposits mostly come from rivers (Cambon et al. 1997) and are representative of the vegetation in the drainage basin (Beaudouin et al. 2005). Because of their high buoyancy, the proportion of Pinus pollen grains is mostly controlled by the distance from river mouths (Heusser \& Balsam 1977). This pollen is generally over-represented in marine sediments (Beaudouin et al. 2007). Pinus percentages are calculated from the total pollen sum whereas the percentages of other taxa are calculated from the total pollen sum without Pinus. All percentages are shown in a detailed diagram (Figs. 3 and 4). Taxa have been grouped according to their estimated ecology defined on the basis of their representatives in the present-day plant ecosystems (Combourieu-Nebout 1987). Groups of vegetation are shown in a synthetic diagram (given both with and without Pinus; Fig. 5), and the main groups are represented in Figure 6 to reconstruct vegetation changes through time.

\section{Macrofossils}

Skeletal aquatic invertebrate and vertebrate remains have been studied to compare the changes in terrestrial vegetation with those occurring in marine settings. Collected sediment samples, weighing 300-800 g, were soaked in water-diluted hydrogen peroxide $(8 \%)$. They were then washed over a column of six sieves with diminishing mesh sizes of $2,1,0.5$, $0.25,0.125$ and $0.063 \mathrm{~mm}$. Only very rare identifiable fossils were observed in the finest fraction. Ten groups of skeletal organisms have been identified: coralline algae (always rare, absent from sequences TS1TS3), foraminifers, corals, molluscs (bivalves, gastropods and very rare scaphopods and polyplacophorans), serpulid worms, bryozoans, brachio- pods, crustaceans (mostly ostracodes, but also scarce decapods and barnacles), echinoderms (essentially echinoids) and fishes (Fig. 5).

\section{Oxygen isotope ratios of carbonates}

Two bivalve shells of Spondylus gaederopus were used for isotopic investigations. The first one was collected alive at a depth of $5 \mathrm{~m}$, off the southern coast of Corsica, where the bivalve lived cemented to rocks. The second shell is a fossil specimen sampled from the LadikoTsampika Formation (TS1-TS3; Fig. 5). The modern Spondylus specimen was selected to determine the extent to which its oxygen isotope composition records seawater temperature in which it grew and how it can be used to interpret data obtained from the fossil Spondylus collected from Tsampika. Submature or mature sections of mollusc shells are preferable for the analysis of carbon and oxygen isotope compositions, to avoid large isotopic fractionation effects of kinetic or metabolic origin (e.g. McConnaughey et al. 1997; Dettman et al. 1999).

Carbonate samples of both Spondylus shells were taken at close intervals $($ c. $2 \mathrm{~mm})$ by drilling the left valve along the growth axis (Tables 1 and 2). Both shells had been cleaned and washed in an ultrasonic bath before sampling with a micro-driller. Oxygen isotope ratios of these carbonate samples have been measured by using a Multiprep ${ }^{\mathrm{TM}}$ automated sample preparation device coupled to a GVI Isoprime $^{\mathrm{TM}}$ stable isotope ratio mass spectrometer configured in dual inlet mode. Between 100 and $200 \mu \mathrm{g}$ of powdered carbonate was reacted with phosphoric acid at $90 \pm 0.1^{\circ} \mathrm{C}$ for $10 \mathrm{~min}$. All samples have been duplicated or triplicated and isotopic compositions have been calibrated to NBS19 and quoted in the delta notation (\%o V-SMOW for $\delta^{18} \mathrm{O}$ and \%o V-PDB for $\delta^{13} \mathrm{C}$ ). Reproducibilities $(1 \sigma)$ were less than $0.15 \%$ or $\delta^{18} \mathrm{O}$ and $0.1 \%$ for $\delta^{13} \mathrm{O}$ values. 


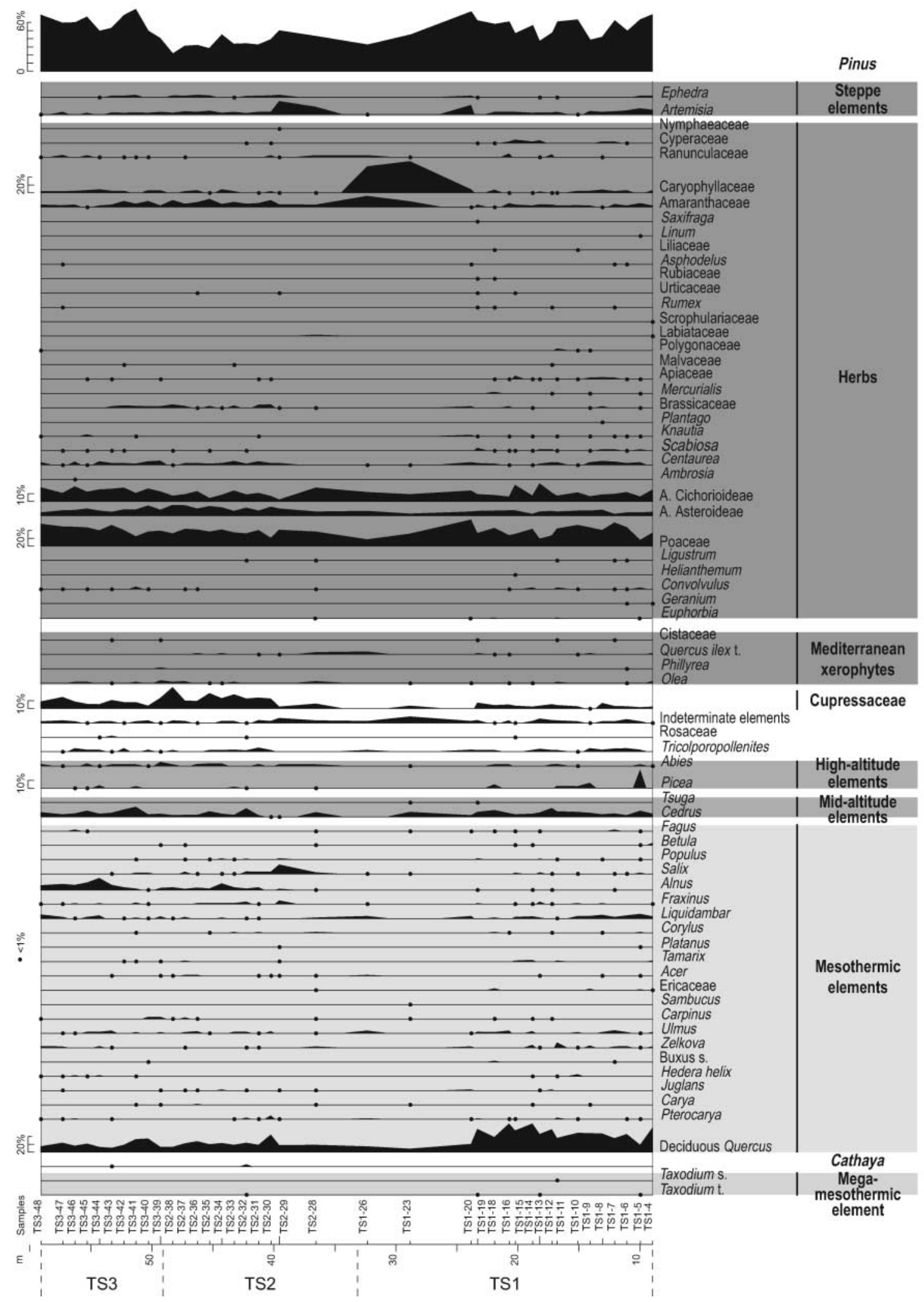

Fig. 3. Detailed pollen diagrams of sequences TS1-TS3. All taxa (except Pinus) are represented in relative percentages, which are calculated according to the total of counted pollen grains minus Pinus. Only Pinus has a relative percentage based on the total of counted pollen grains. Taxonomic groups are based on the ecological significance of their present-day representatives: mesothermic elements (e.g. deciduous Quercus, Carya and Pterocarya), midaltitude elements (Cedrus and Tsuga), high-altitude elements (Picea and Abies), Mediterranean xerophytes (such as Olea), herbs (e.g. Poaceae, Asteraceae, Asteroideae) and steppe elements (e.g. Artemisia and Ephedra). 


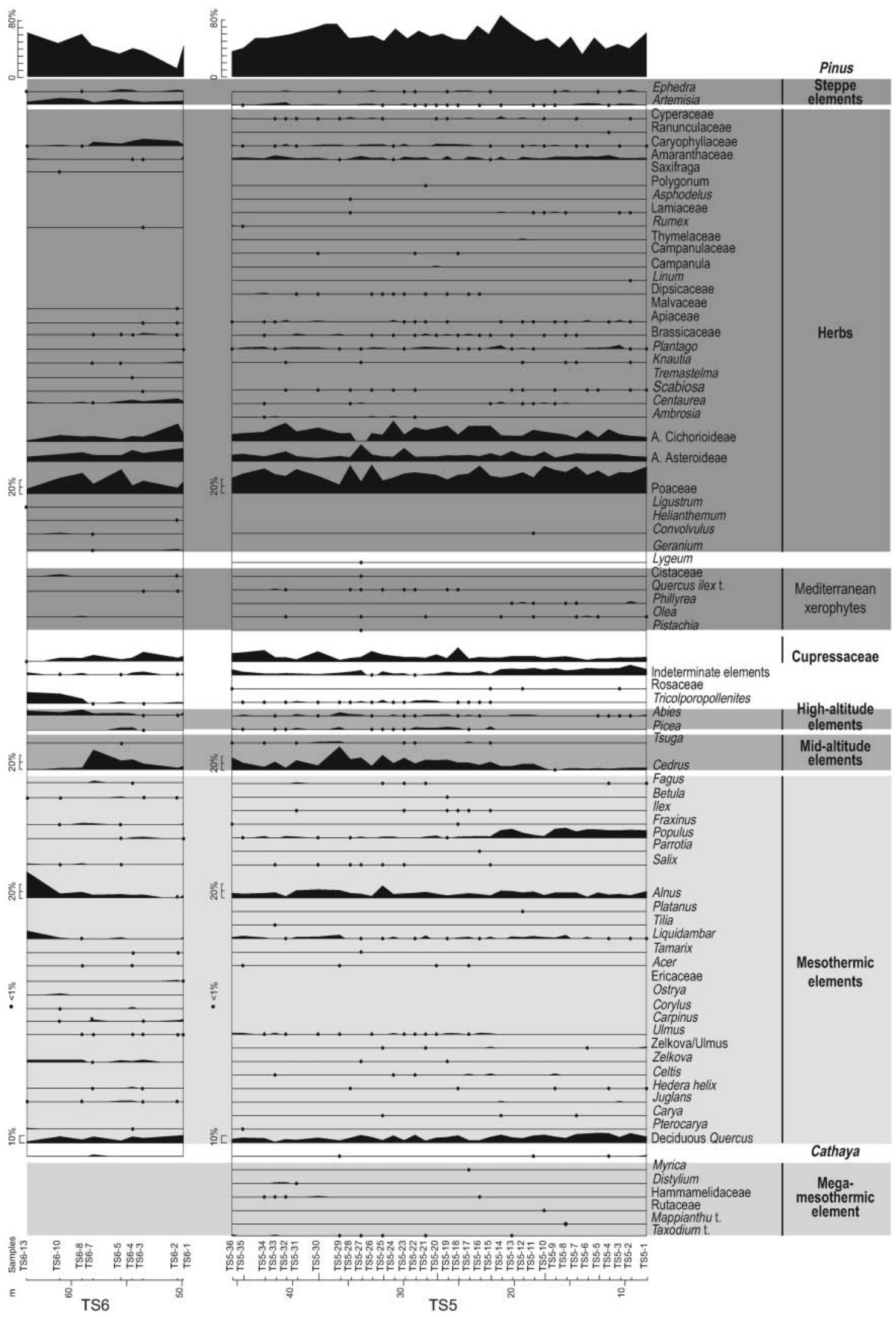

Fig. 4. Detailed pollen diagrams of sequences TS5 and TS6. (See caption of Figure 3 for explanation.) 


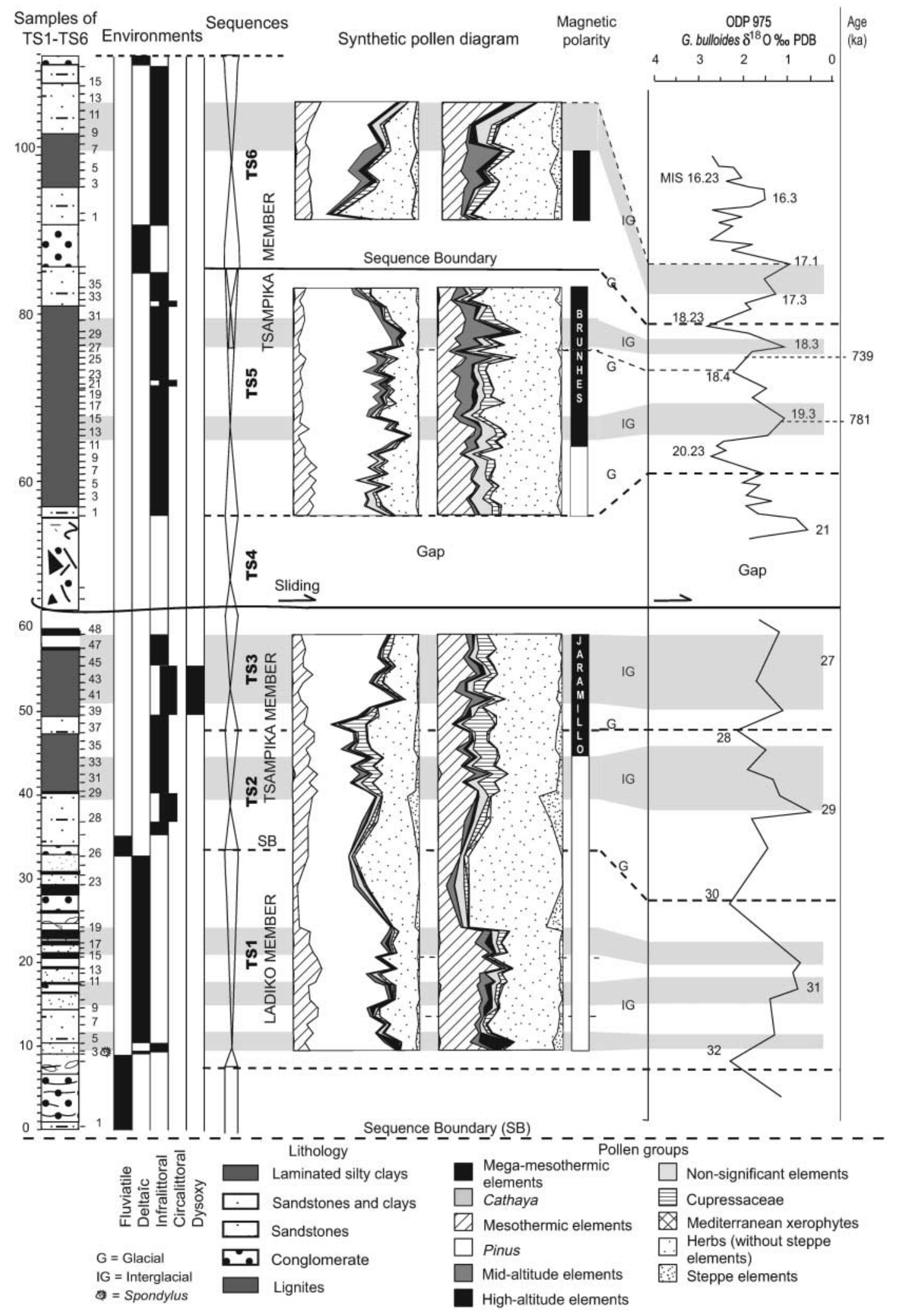

Fig. 5. Synthetic diagrams showing lithology, faunal components, sequences and pollen content (with and without Pinus) compared with isotopic correlations. Maximum water depth suggested by Pinus content is highlighted in grey. 
Decomposed synthetic pollen diagram
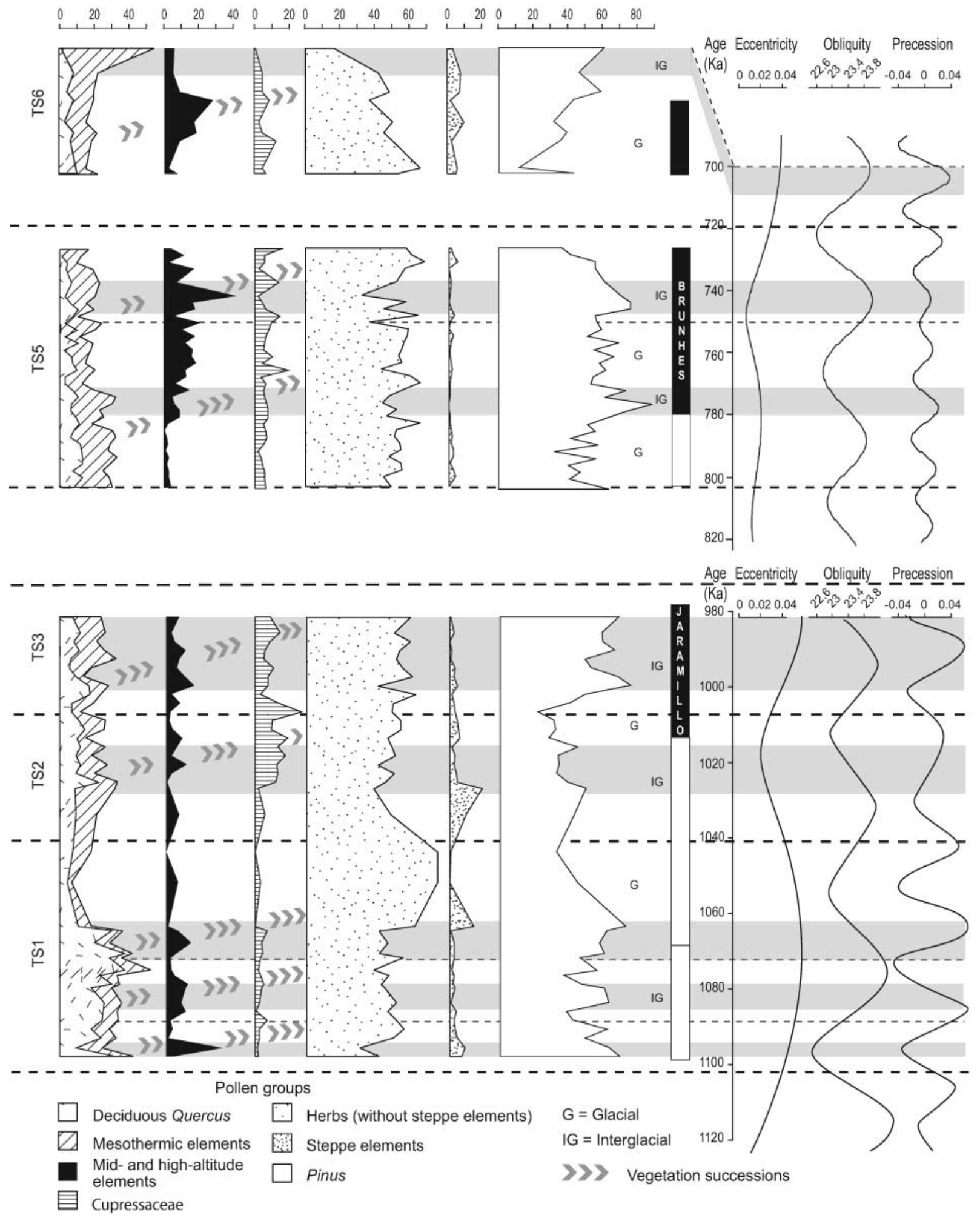

Fig. 6. Synthetic pollen diagram showing vegetational successions linked to variations in orbital parameters (Laskar et al. 2004) calibrated to magnetostratigraphic results (Cornée et al. 2006). Taxonomic groups are given in percentages (based on total pollen except Pinus). 
Table 1. Carbon and oxygen isotope data obtained on carbonate samples extracted along the growth axis of Spondylus gaederopus shell from Corsica

\begin{tabular}{lccc}
\hline Sample & Length $(\mathrm{mm})$ & $\delta^{13} \mathrm{C}(\mathrm{PDB})$ & $\delta^{18} \mathrm{O}(\mathrm{PDB})$ \\
\hline Cors-1 & 5 & 1.49 & 1.85 \\
Cors-2 & 8 & 1.57 & 1.50 \\
Cors-3 & 11 & 1.44 & 1.40 \\
Cors-4 & 14 & 1.20 & 0.73 \\
Cors-5 & 17 & 1.26 & 1.46 \\
Cors-6 & 20 & 1.05 & 1.20 \\
Cors-7 & 23 & 0.81 & 0.95 \\
Cors-8 & 26 & 0.83 & 1.08 \\
Cors-9 & 29 & 0.75 & 0.51 \\
Cors-10 & 32 & 0.75 & 0.93 \\
Cors-11 & 35 & 0.66 & 0.37 \\
Cors-12 & 38 & 0.71 & 0.96 \\
Cors-13 & 41 & 0.68 & 1.08 \\
Cors-14 & 44 & 0.74 & 0.40 \\
Cors-15 & 47 & 0.39 & 0.72 \\
Cors-16 & 50 & 0.69 & 0.94 \\
Cors-17 & 53 & 0.55 & 0.69 \\
Cors-18 & 56 & 0.66 & 0.52 \\
Cors-19 & 59 & 0.59 & 1.16 \\
Cors-20 & 62 & 0.60 & 0.90 \\
Cors-21 & 65 & 0.44 & 0.67 \\
\hline
\end{tabular}

Table 2. Carbon and oxygen isotope data obtained on carbonate samples extracted along the growth axis of Spondylus gaederopus shell from the Tsampika section

\begin{tabular}{lrrr}
\hline Sample & Length $(\mathrm{mm})$ & $\delta^{13} \mathrm{C}(\mathrm{PDB})$ & $\delta^{18} \mathrm{O}(\mathrm{PDB})$ \\
\hline Tss3-A & 20 & -2.87 & -1.45 \\
Tss3-B & 22 & -2.09 & -1.46 \\
Tss-C & 24 & -0.31 & -0.26 \\
Tss-D & 26 & 0.26 & -0.14 \\
Tss-E & 28 & 0.03 & -0.70 \\
Tss-F & 30 & 0.08 & -0.09 \\
Tss-G & 32 & 1.05 & 0.27 \\
Tss-H & 34 & 0.86 & 0.15 \\
Tss-I & 36 & 1.06 & 0.01 \\
Tss-J & 38 & 1.27 & 0.14 \\
Tss-K & 40 & 1.00 & 0.24 \\
Tss-M & 44 & 1.22 & 0.29 \\
Tss-N & 46 & 0.83 & -0.77 \\
Tss-O & 48 & 1.52 & 0.04 \\
Tss3-P & 50 & 1.25 & -0.01 \\
Tss3-Q & 52 & 1.36 & 0.48 \\
Tss3-R & 54 & 0.77 & -0.06 \\
Tss3-T & 58 & 0.75 & 0.30 \\
Tss3-U & 60 & 0.70 & -0.26 \\
Tss3-V & 62 & 1.23 & 0.68 \\
Tss3-X & 66 & 0.46 & 0.55 \\
\hline
\end{tabular}

\section{Results}

\section{Pollen analysis}

The following pollen taxa have been identified in the Tsampika Formation: (1) common mesothermic Early-Middle Pleistocene typical taxa of the Mediterranean region, which are Carya, Zelkova, Pterocarya and Liquidambar; (2) mid-altitude taxa such as Cedrus and Tsuga; (3) subtropical elements represented by rare pollen grains of Cathaya, which is a mid-altitude relict conifer restricted today to China, and also by mega-mesothermic Taxodiaceae (Figs. 3 and 4).
Specific vegetation patterns of the Tsampika Formation are marked by the abundance of Cupressaceae, irrespective of the relative proportions of other taxa, and by the scarcity of Artemisia.

As indicated in Figure 5 and discussed by Cornée et al. (2006), facies changes in the Tsampika section are related to eustatic changes. Those workers also correlated the abundance of Pinus pollen with the observed sedimentary changes; shoreface facies contain less Pinus pollen than offshore facies. They also noticed that taxa requiring warm to temperate and humid conditions (i.e. Quercus, Cedrus, Abies) were abundant in the offshore deposits of the sequences whereas taxa indicative of cold and more arid conditions (i.e. Artemisia, Asteraceae, Asteroideae) were abundant in shallow-water sediments. Cornée et al. (2006) interpreted these observations as sea-level changes that were probably coeval with glacial-interglacial cycles.

\section{Correlation with marine oxygen isotopic stages}

Cornée et al. (2006), on the basis of palaeomagnetic results, indicated the presence of the Jaramillo subchron (1.070$0.990 \mathrm{Ma}$, Berggren et al. 1995) and placed the onset of the Brunhes Chron (0.780 Ma, Berggren et al. 1995; $0.773 \mathrm{Ma}$, Channel et al. 2004) at the top of TS2 and in the lower part of TS5, respectively. These ages also correspond to MIS 31-27 and MIS 19, respectively (Maslin \& Ridgwell 2005). This result allows a partial correlation between the pollen synthetic diagrams and the Mediterranean oxygen isotope curve established with the planktonic foraminifer Globigerina bulloides of Ocean Drilling Program (ODP) Site 975 (De Kaenel et al. 1999; Fig. 5). We used the successive vegetation replacements and the relative abundance of Pinus as an eustatic proxy of glacialinterglacial cycles to refine the stratigraphic correlation.

\section{Climate record and vegetation dynamics}

Sequence TS1 is dated from MIS 31-30 on the basis of the relative chronology proposed above (Fig. 5). Recently, Joannin (2007) observed three sub-phases of high abundance of mesothermic elements during the interglacial MIS 31 throughout the Mediterranean area. The long warm period at the base of TS1, also including three sub-phases, is thus attributed to MIS 31. This long warm climate phase is followed by a very cold climate phase MIS 30. This cold episode corresponds to a major regression at the end of TS1. TS2 correlates with MIS 30-MIS 28. The record of MIS 29, however, is poorly marked in the pollen diagram. The low resolution of the pollen analyses in the sandy beds probably hides a part of the climatic signal because only two samples yielded pollen grains within a $12.5 \mathrm{~m}$ interval. TS3 started during MIS 28 and recorded a warm phase corresponding to MIS 27. Its uppermost part is truncated by the slumped TS4 sequence. Our time-calibration indicates that TS4 corresponds to MIS 27-MIS 20 and TS5 to MIS 20-MIS 18, respectively. Furthermore, the sedimentary record and the Pinus variations fitted the same MIS 18 internal variations (MIS 18.3 of ODP Site 975, Fig. 5). The pollen record of TS6 correlates with a warming episode related to MIS 17.

The vegetation patterns observed in the pollen diagrams can be separated into eight vegetation successions (arrows in Fig. 6). They are characterized by the dominance of mesothermic elements, followed by mid- and high-altitude elements with Pinus, and end with maxima in herb and steppe elements. Each vegetation succession consequently shows a replacement of mesothermic elements typical of warm-temperate conditions by 
altitudinal vegetation indicating cooler conditions and then by herb and steppe elements that characterize colder and dryer conditions. These three phases of the vegetation succession mainly include deciduous Quercus, Cedrus and Poaceae, respectively. The refined time calibration of the Tsampika section allows the correlation of vegetation successions with the variations in orbital parameters (Laskar et al. 2004; Fig. 6). Most warming periods, indicated by mesothermic elements and increases in Pinus, correspond to obliquity maxima. However, timing of obliquity variations and MIS of ODP Site 975 are not exactly similar to the sequences and vegetation changes in Tsampika. During the deposition of TS1-TS3, the sequences and the Pinus variations are in better accord with the record of the Mediterranean oxygen isotopic record than with the record of the orbital variations. The minimum of obliquity at the base of TS1 corresponds to the beginning of interglacial MIS 31. The beginning of TS5 is marked by a discrepancy between obliquity-mesothermic maxima and maxima of Pinus abundance. The first and third vegetation successions recorded in TS1 should be a response to climate changes induced by precession minima. Similarly, two phases of warm vegetation are recorded in TS3. They can be related to precession minima. In contrast, the precession effect on vegetation changes in TS5 and TS6 is not clearly observed. It might result from the low-amplitude changes in the precession variations at about $0.800-0.700 \mathrm{Ma}$. These low-amplitude precession variations result from low eccentricity variations (Fig. 6).

\section{Marine biota}

The analysis of the aquatic skeletal organisms shows that most samples contain low-diversity assemblages. Four types of depositional environments have been recognized in the Tsampika section (Fig. 5): freshwater (fluviatile to possibly limnic), brackish (deltaic or lagoonal), marine infralittoral and marine circalittoral. Depositional water depth for all sequences of the small semi-enclosed Tsampika basin was probably never more than about $50 \mathrm{~m}$. Dysoxic periods are also recorded by invertebrate assemblages from parts of the marine intervals (Fig. 5).

In sequence TS1 the first two fossil-free conglomeratic samples are interpreted as fluviatile in origin. They are overlain by brackish-water sediments, except sample 4, which was deposited during a brief marine episode. The brackish-water sediments contain gypsum crystals, coal particles, benthic foraminifers (predominantly Ammonia becarii and Elphidium spp.), bivalves (Mactra sp., Cerastoderma sp.), and gastropods (cerithids, Terebralia sp.). Sequences TS2 and TS3, separated by a short fossil-poor interval, are fully marine. They are characterized by the occurrence of foraminifers with abundant planktonic species in some levels, molluscs accompanied by scarce pteropods, ostracodes and generally rare to very rare bryozoans and echinoids. The mollusc associations indicate either the infralittoral (Anomia ephippium, Spondylys gaederopus, Chlamys multistriata, Conus mediterraneus and Dosinia lupinus, Lissopecten hyalinus, Thracia convexa, Haustator tricarinatus) or the circalittoral (Corbula gibba, Parvicardium exiguum, Palliolum incomparabile, Epitonium aculeatum, Dentalium sp. and Odostomia conoidea, Euclio cuspidata) depositional environments. In some cases, laminated beds, abundant bolivines, and mollusc shells such as Corbula gibba and Parvicardium exiguum indicate deposition under various oxic conditions. The laminated silty clays of sequence TS5 are characterized by a poor association of bivalves, especially Nucula and Mactra, and ostracodes, together with very rare benthic and planktonic foraminifers, extremely rare bryozoans and echinoids, and some coal particles. These features suggest water stratification and therefore accumulation of organic matter on the sea floor, possibly leading to eutrophication and reduced levels of dissolved oxygen. The shelly sandstones at the base of TS6 show a strong increase in abundance and diversity of benthic infralittoral skeletal fauna: foraminifers, corals, molluscs, serpulids, bryozoans, ostracodes, barnacles, and echinoids. This faunal association implies normal-marine conditions with a well-oxygenated sea floor. In contrast, the overlying clayey facies contains only few fossils and probably corresponds again to poorly oxygenated depositional environments. The appearance of mollusc-rich sandstones at the top of TS6 indicates the return to normal marine conditions with a mixed assemblage of rocky and sandy bottom infralittoral communities. Several specimens of the boreal Atlantic bivalve Arctica islandi$c a$ have been found at the top of sequence TS6. This species is considered a 'boreal guest' indicating lower water temperature than at present (Raffi 1986).

Accumulation rates deduced from our time scale are estimated as high, about $4.5 \pm 0.5 \mathrm{~mm} \mathrm{a}^{-1}$ for TS1-TS3, $4.5 \pm$ $0.5 \mathrm{~mm} \mathrm{a}^{-1}$ for TS5, and $4.7 \pm 0.75 \mathrm{~mm} \mathrm{a}^{-1}$ for TS6. These high accumulation rates probably did not favour the development of a rich benthic fauna except in the shoreface areas.

\section{Stable isotopes}

The modern Spondylus from Corsica has $\delta^{13} \mathrm{C}$ values that decrease regularly from $1.5 \%$ to $0.5 \%$ with increasing ontogenetic age whereas $\delta^{18} \mathrm{O}$ values show repeated fluctuations $<1 \%$ in amplitude with the highest values approaching $2 \%$ close to the shell umbo (Fig. 7a). The fossil Spondylus from Tsampika section is characterized by co-varying $\delta^{13} \mathrm{C}$ and $\delta^{18} \mathrm{O}$ values that approximately increase from $-3 \%$ to $1 \%$ and from $-1.5 \%$ o to $0 \%$, respectively (Fig. $7 \mathrm{~b}$ ). It is noteworthy that both isotopic compositions increase over the first centimetre from the

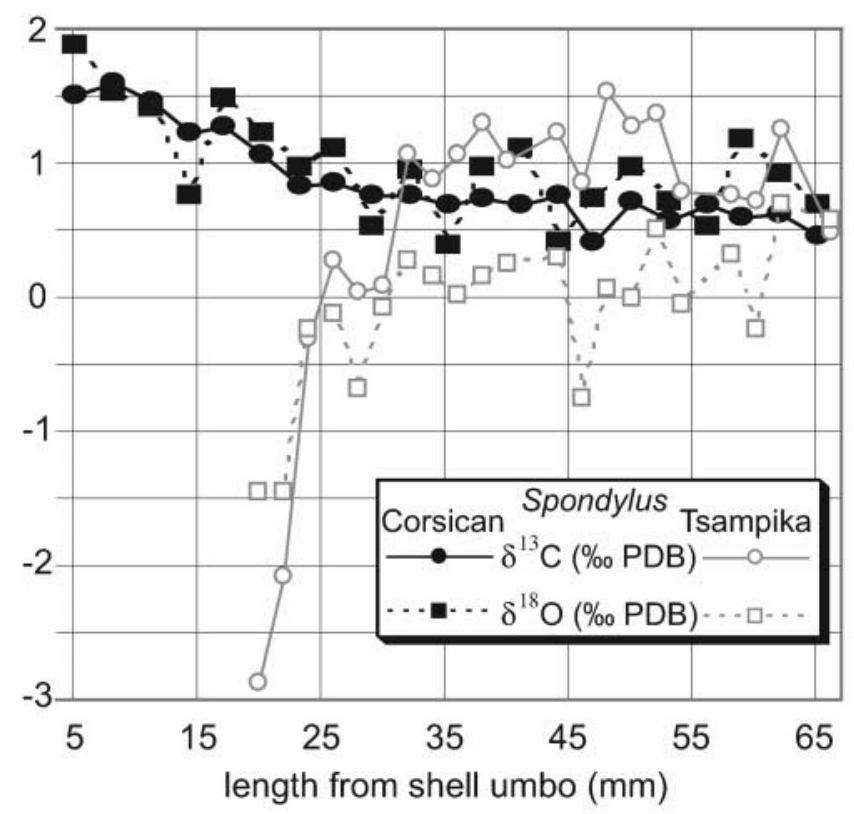

Fig. 7. Carbon and oxygen isotope values from modern Corsican and Pleistocene Tsampika spondylids (sample TS1-TS3 in Fig. 5). Values are given in Tables 1 and 2. 
shell umbo then remain at steady-state values except for sample Tss-N (Table 1). If we consider only the 'adult' parts of both Spondylus, i.e. the last $3 \mathrm{~cm}$ of shell growth, they are characterized by rather constant carbon and oxygen isotope compositions. For both shells, $\delta^{13} \mathrm{C}$ values are about $1 \%$ on average whereas the average $\delta^{18} \mathrm{O}$ value of modern Corsican Spondylus is $1 \%$ higher than that of its fossil counterpart from Rhodes.

In the fossil Spondylus, low $\delta^{13} \mathrm{C}$ and $\delta^{18} \mathrm{O}$ values are observed in the juvenile shell part relative to the adult one; such a pattern has been already documented for the first septa of Nautilus shells (Cochran et al. 1981; Taylor \& Ward 1983; Crocker et al. 1985). This isotopic pattern is not observed in the juvenile part of the modern Corsican Spondylus shell (Fig. 7a). The shell close to the umbo could have suffered some diagenetic alteration responsible for a decrease of both $\delta^{13} \mathrm{C}$ and $\delta^{18} \mathrm{O}$ values relative to pristine isotopic compositions. However, diagenetic fluids are commonly aqueous and modify $\delta^{18} \mathrm{O}$ values of carbonates with a much larger amplitude than for $\delta^{13} \mathrm{C}$ values. If we focus on the isotopic compositions of the adult parts of both Spondylus shells, we observe that similar average $\delta^{13} \mathrm{C}$ values of $1 \%$ have been recorded, in agreement with the marine composition of dissolved carbon, which is close to $1.2 \pm 0.1 \%$ off Rhodes (Pierre 1999).

\section{Discussion}

\section{Past phytogeography}

The Early to Middle Pleistocene vegetation of Rhodes is similar to the modern vegetation of southern Turkey described above. Several Pleistocene taxa (Quercus, Pinus, Cupressaceae and Cedrus) common to both Rhodes and Turkey point to a past wider extension of the modern Turkish phytogeographical units because these areas were part of the same emerged region until the Early Pliocene (Ten Veen \& Kleinspehn 2002). Deciduous Quercus and Cedrus survived during the Early and Middle Pleistocene in Rhodes despite low elevations (now about $600 \mathrm{~m}$ ). The onset of the xeric conditions during the latest climatic cycles finally led to the present-day absence of these taxa in the lowelevation island of Rhodes. In the same way, even during the glacial episodes, the low altitudes of Rhodes probably did not allow drier and colder conditions which are generally required for steppes (Subally \& Quézel 2002).

Horowitz (1989), Subally et al. (1999) and Suc \& Popescu (2005) proposed a climatic duality regarding both dryness and wetness parameters between western and eastern Mediterranean regions since the Late Pliocene. In Zakynthos (Greece), Subally et al. (1999) observed high Artemisia values in the pollen diagram, indicating dry climate during interglacial phases determined by foraminiferal isotopic measurements and correlated with MIS 69, 67 and 65. During the same period, the Crotone series (Italy) have recorded wet interglacial phases (CombourieuNebout et al. 1990; Combourieu-Nebout 1993). In Tsampika, the glacial episodes are characterized by a dry climate and interglacial phases by a wet climate, a climatic mode also observed in the western Mediterranean region (Capraro et al. 2005). Despite low values of Artemisia, the occurrence of this xeric genus in Tsampika is correlated with the glacial phases. This conclusion, which is in agreement with the results given by CombourieuNebout (1993) for the Upper Pliocene sequence of Crotone, does not support the hypothesis of a climatic duality between western and eastern Mediterranean regions during the late Early and Middle Pleistocene.

\section{Vegetation and orbital parameters}

From the Late Pliocene to the Early Pleistocene, the dominant frequency response of the climate system to orbital forcing resulted in $41 \mathrm{ka}$ obliquity-induced climatic cycles (Pisias \& Moore 1981; Kroon et al. 1998; Ruddiman 2003). After the Middle Pleistocene (at 0.9-0.8 Ma; Von Grafenstein et al. 1999; Ruddiman 2003), the climate responded mainly to combinations of eccentricity and precession resulting in $100 \mathrm{ka}$ climatic cycles. The replacement of obliquity cycles by $100 \mathrm{ka}$ cycles has been placed later (at 0.620 Ma) by Mudelsee \& Stattegger (1997). For Head \& Gibbard (2005), this dominant frequency replacement should be progressive. Tsampika sedimentation was controlled by climatic cycles (Cornée et al. 2006), extending from MIS 31 to MIS 17 in agreement with our new time calibration. The first three sequences, corresponding to MIS 31-27, occurred at a time when climate responded to obliquity forcing. Despite the lack of MIS 27 to MIS 20, the other MIS occurred during obliquity cycles (Mudelsee \& Stattegger 1997; Maslin \& Ridgwell 2005) or during $100 \mathrm{ka}$ cycles (Von Grafenstein et al. 1999; Ruddiman 2003). Even if the Tsampika section recorded only six climatic cycles, so that the evolution of the vegetation response to orbital cycles cannot be continuously followed, the change in vegetation response could record changes in climate system response to orbital parameters in the studied intervals.

Because of its impacts on insolation in high northern latitudes (Berger \& Loutre 2004), obliquity influences decametre-scale eustatic variations as recorded in the Tsampika basin. Throughout the section, we identified a suitable link between vegetation successions and obliquity variations (Fig. 6). The dominant obliquity-driven frequency record in vegetational successions was observed by Mommersteeg et al. (1995) in northern Greece for the Middle Pleistocene. We therefore propose that this dominance existed also during the Early Pleistocene. Nevertheless, precession had a greater influence on insolation than obliquity at low latitudes such as the location of Rhodes (Rossignol-Strick \& Paterne 1999; Shackleton et al. 1999; Maslin \& Ridgwell 2005). Generally, the impact of precession on the Tsampika vegetation is poorly recorded (Fig. 6). As the sampling resolution is sufficient (one sample each metre, i.e. $c$. 2000 years), this probably could result from the low elevation of the island, where movements of vegetation belts were not marked enough to be recorded in the pollen content of sediments. However, vegetation changes sometimes appear to be related to precession, as in TS1 and TS3. Such a relation exists when precession amplitude variations (modulated by eccentricity) are high. This is the case during the first and third vegetation successions of TS1, which are also well expressed across the Mediterranean area (Joannin 2007), and during the characteristic two sub-phases of the MIS 27 cycle.

\section{Climatic cycles and chronostratigraphy}

From MIS 31 to MIS 27 (sequences TS1-TS3), vegetation changes, sedimentation and oxygen isotope ratios of foraminifers argue in favour of dominant climate response to obliquity. Palynological, sedimentological and palaeontological changes in marine deposits observed in TS5 and TS6 correlate with climate cycles related to obliquity, and correspond to MIS 20-17. This is in opposition to the 100 ka climate cycles since $0.9 \mathrm{Ma}$ (Pisias \& Moore 1981; Kroon et al. 1998; Ruddiman 2003) but is in accordance with the dominant frequency response of the climate system to obliquity from the beginning of the Middle Pleistocene to 0.62 Ma (Mudelsee \& Stattegger 1997; Maslin \& Ridgwell 
2005). Thus, the glacio-eustatic control of sedimentation of the unstudied sequences (TS7, TS8 and TS9) was suggested to be $100 \mathrm{ka}$ cycles until 0.4-0.3 Ma (Cornée et al. 2006). An age of around $0.3 \mathrm{Ma}$ is likely for the top of the uppermost TS9 sequence, as the base of sequence TS7 corresponds to the onset of the $100 \mathrm{ka}$ cycles dated at $620 \mathrm{ka}$ (MIS 16; Maslin \& Ridgwell 2005).

Incidentally, our new calibration reduces the elevation rate for Rhodes. Indeed, a major uplift occurred just before the LadikoTsampika Formation deposits, previously considered to begin at 1.3 Ma (Cornée et al. 2006). The rate of uplift had been estimated at about $5.2 \mathrm{~mm} \mathrm{a}^{-1}$ (Cornée et al. 2006). The proposed calibration of the Tsampika section (1.1-0.3 Ma) gives an age of about 1.2 Ma for the Ladiko-Tsampika Formation basal deposits. The elevation of Rhodes was thus active for $200 \mathrm{ka}$ (not $100 \mathrm{ka}$ ) and the rate of uplift can be corrected at about $2.6 \mathrm{~mm} \mathrm{a}^{-1}$. This value is still high but it is now close to those calculated in highly active areas (e.g. the Gulf of Corinth; Stiros 1998).

\section{Water temperatures and environment of the Tsampika basin}

The $\delta^{18} \mathrm{O}$ values of the modern Corsican adult Spondylus shell indicate an 'isotopic temperature' of $24{ }^{\circ} \mathrm{C}$ calculated from the equation of Grossman \& $\mathrm{Ku}(1986)$ with a seawater $\delta^{18} \mathrm{O}$ value of $1.5 \%$ (Pierre 1999). This temperature is $6{ }^{\circ} \mathrm{C}$ higher than the average seawater temperature of $18^{\circ} \mathrm{C}$ provided by the oceanographic data off Corsica (Levitus 1994). This temperature bias probably results from a temperature-dependent growth mode, which is already known for other molluscs (e.g. Cornu et al. 1993). At mid-latitudes, shell growth mainly occurs during warm seasons, thus explaining why the expected sinusoidal isotopic variations are not recorded in the studied shell. The fossil Spondylus adult shell from Tsampika allows the calculation of a temperature of $28^{\circ} \mathrm{C}$ by assuming a $\delta^{18} \mathrm{O}$ of seawater equal to $1.8 \%$ and identical to the value for the present-day seawater surface off Rhodes (Pierre 1999). As a first approximation, we can apply to the fossil shell the same temperature bias as above, leading to an estimate of the mean seawater temperature of $22{ }^{\circ} \mathrm{C}$. This temperature is slightly higher but remains comparable with the present-day average seawater temperature of $20^{\circ} \mathrm{C}$ off Rhodes (Levitus 1994), taking into account uncertainties associated with the oxygen isotope record in the fossil shell. This result suggests that the Spondylus lived in a warm water mass compatible with the climatic conditions of the interglacial phase corresponding to MIS 31 proposed from our climatic model.

The Tsampika basin was semi-enclosed (Fig. 2a), and was subsiding as indicated by at least $160 \mathrm{~m}$ of sediment thickness. It opened seaward to the south through a narrow strait and was filled by detrital sediments probably carried by river flow from the north. Because of the peculiar geometry of the basin and the abundance of clayey sediments, the Tsampika Member contains sparse planktonic and benthic open-sea organisms. The clayey infralittoral to circalittoral sediments are often barren of current sedimentary features and reveal only thin laminations, indicating quiet depositional environments during high sea levels. In some cases, dysoxic environments prevailed in these argillaceous deposits. At the same time, the abundance of encrusting spondylids and oysters and boring lithophagid bivalves on submarine palaeocliffs implies prevailing normal marine surfacewater conditions. These observations suggest a probable stratification of the water column in this small semi-enclosed basin. During lower sea levels, sedimentation operated in shallow open and oxygenated waters locally containing a diverse fauna. During glacial periods the sea level dropped. That favoured either the deposition of upper shoreface deposits that contain cold-water fauna (e.g. Arctica islandica in sequence TS6), or deltaic to fluviatile sediments (TS1, TS2, TS5 and TS6; Fig. 5). During interglacial stages, the sea level rose (base of sequences TS1, TS2 and TS6) and shallow-water sands were deposited, inhabited by warm-temperate marine fauna (Pecten jacobaeus, Barbatia barbata, Spondylus gaederopus, Mitra fusiformis, Bittium reticulatum, Chlamys multistriata, Pitar rudis). Then, with the deepening of the basin, the marine circulation slowed down and dysoxic bottom conditions sometimes developed in relation to clayey deposits. The first phase of interglacial stages, expressed by marine invasion and the appearance of warm-temperate faunas, corroborates the climatic changes established from pollen analysis and oxygen isotope correlations.

\section{Conclusion}

Palynological, sedimentological and palaeontological variations indicate a glacio-eustatic control for the sedimentary sequences identified in the Tsampika section. Eight vegetation successions are related to climatic cycles defined by using the Mediterranean oxygen isotope ratios provided by ODP Site 975 and to obliquity variations. We propose a refined age for the five sequences studied in the Tsampika section from MIS 31 to MIS 27 and from MIS 20 to MIS 17. A dominant frequency climatic response to obliquity was observed in vegetation dynamics during these periods and our results corroborate the hypothesis of climate response to obliquity until $0.62 \mathrm{Ma}$. Climatic response to the influence of precession is clearly marked in the vegetation changes recorded in TS1 and TS3 deposits when amplitudes modulated by eccentricity were high. In contrast, precession effects are poorly recorded in TS5 and TS6. Orbital and glacioeustatic controls of sedimentation allow a better age estimation of around 1.1 Ma for the base of the first sequence (TS1) and of around $0.3 \mathrm{Ma}$ for the last sequence (TS9). As a consequence, the beginning of Ladiko-Tsampika Formation deposits is estimated to date at c. 1.2 Ma. This age indicates that the previous Rhodes uplift was active for around $200 \mathrm{ka}$, at a rate of about $2.6 \mathrm{~mm} \mathrm{a}^{-1}$. At Tsampika, tectonics had a minor influence on the genesis of sequences, controlling only global subsidence and the dismembering of TS4, which is assumed to record MIS 27-MIS 20 events.

Palynological analyses reveal relationships between past and present phytogeography. Past vegetation was composed of Quercus, Pinus, Cupressaceae and Cedrus. Pinus and Cupressaceae still exist in Rhodes whereas the four taxa occur today on the seaward sides of Turkish mountains. This pattern indicates a common origin of these taxa as well as the disappearance of Quercus and Cedrus, which might have resulted from a recent drier climate and the low elevations of the island. Such a scenario could explain the poor records of Artemisia, even during glacial stages, as well as the vegetation changes related to precession. The proposed dryness-wetness duality between the western and eastern Mediterranean during the Late Pliocene was not identified in the Early-Middle Pleistocene deposits of Tsampika.

The mean seawater temperature of $22{ }^{\circ} \mathrm{C}$ estimated from the oxygen isotope composition of the fossil Spondylus shell is slightly higher than the present-day average seawater temperature of $20{ }^{\circ} \mathrm{C}$ off Rhodes. This bivalve lived in a warm water mass compatible with the climatic conditions of an interglacial phase. The study of macrofossil associations also indicates warm- 
temperate fauna during marine invasions related to interglacial phases. All these results lead us to conclude that the interglacial stages were characterized by shallow-water sandy deposits with warm-temperate marine fauna, followed by a deepening of the microbasin, a stratification of the water mass, and the onset of dysoxic conditions on the muddy bottom.

Thanks are extended to G. Jiménez-Moreno, G. Escarguel, E. Cortijo, P. Carbonel and F. Quillévéré for their help. Fieldwork was initially funded by a research grant from the French CNRS-Greek NHRF agreement for scientific co-operation. Research was later supported by the CNRS (UMR 5125 PEPS) and the Institut Universitaire de France. M. J. Head and an anonymous reviewer are thanked for their constructive comments on an earlier version of the manuscript. This paper is Publication UMR 5125 Number 5125-07.003.

\section{References}

Beaudouin, C., Suc, J.-P. \& Cambon, F. ET AL. 2005. Present-day rhythmic deposition in the Grand Rhône prodelta (NW Mediterranean) according to high-resolution pollen analyses. Journal of Coastal Research, 21, 292-306.

Beaudouin, C., Suc, J.-P., Escarguel, G., Arnaud, M. \& Charmasson, S. 2007. The significance of pollen records from marine terrigenous sediments: the present-day example of the Gulf of Lions (Northwestern Mediterranean Sea). Geobios, 40, 159-172.

Berger, A. \& Loutre, M.F. 2004. Théorie astronomique des paléoclimats. Comptes Rendus, Géoscience, 336, 701-709.

Berggren, W.A., Hilgren, F.J. \& Langereis, C.G. et AL. 1995. Late Neogene chronology: new perspective in high-resolution stratigraphy. Geological Society of America Bulletin, 107, 1272-1287.

Cambon, G., Suc, J.-P. \& Aloisi, J.-C. ET AL. 1997. Modern pollen deposition in the Rhône delta area (lagoonal and marine sediments), France. Grana, 36, $105-113$.

Capraro, L., Asioli, A., Backman, J., Bertoldi, R., Channell, J.E.T., Massari, F. \& RiO, D. 2005. Climatic patterns revealed by pollen and oxygen isotope records across the Brunhes-Matuyama boundary in the Central Mediterranean (Southern Italy). In: Head, M.J. \& Gibbard, P.L. (eds) Early-Middle Pleistocene Transitions: The Land-Ocean Evidence. Geological Society, London, Special Publications, 247, 159-182.

Channel, J.E.T., Curtis, J.H. \& Flower, B.P. 2004. The Matuyama-Brunhes boundary interval $(500-900 \mathrm{ka})$ in North Atlantic drift sediments. Geophysical Journal International, 158, 489-505.

Cochran, J.K., Tye, D.M. \& Landman, N.H. 1981. Growth rate and habitat of Nautilus pompilius inferred from radioactive and stable isotope studies. Paleobiology, 7, 469-480.

Combourieu-Nebout, N. 1987. Les premiers cycles glaciaire-interglaciaire en région méditerranéenne d'après l'analyse palynologique de la série pliopléistocène de Crotone (Italie méridionale). $\mathrm{PhD}$ thesis, University Montpellier 2 .

Combourieu-Nebout, N. 1993. Vegetation response to Upper Pliocene glacial/ interglacial cyclicity in the Central Mediterranean. Quaternary Research, 40, $228-236$.

Combourieu-Nebout, N. \& Vergnaud-Grazzini, C. 1991. Late Pliocene northern hemisphere glaciations: the continental and marine responses in the central Mediterranean. Quaternary Science Reviews, 10, 319-334.

Combourieu-Nebout, N., Semah, F. \& Duubiantono, T. 1990. The PlioPleistocene boundary: magnetostratigraphic and climate information from a detailed analysis of the Vrica stratotype (Crotona, Italy). Comptes Rendus de l'Académie des Sciences, 311, 851-857.

Cornée, J.-J., Moissette, P. \& Joannin, S. et al. 2006. Tectonic and climatic controls on coastal sedimentation: the Late Pliocene-Middle Pleistocene of northeastern Rhodes, Greece. Sedimentary Geology, 187, 159-181.

Cornu, S., PÄtzold, J., Bard, E., Meco, J. \& Cuerda-Barcelo, J. 1993. Palaeotemperature of the last interglacial period based on $\delta^{18} \mathrm{O}$ of Strombus bubonius from the western Mediterranean Sea. Palaeogeography, Palaeoclimatology, Palaeoecology, 103, 1-20.

Cour, P. 1974. Nouvelles techniques de détection des flux et de retombées polliniques: étude de la sédimentation des pollens et des spores à la surface du sol. Pollen et Spores, 16, 103-141.

Crocker, K.C., Deniro, M.J. \& Ward, P.D. 1985. Stable isotopic investigations of early development in extant and fossil chambered cephalopods. 1. Oxygen isotopic composition of eggwater and carbon isotopic composition of siphuncle organic-matter in Nautilus. Geochimica et Cosmochimica Acta, 49, 2527-2532.

De Kaenel, E., Siesser, W.G. \& Murat, A. 1999. Pleistocene calcareous nannofossil biostratigraphy and the western Mediterranean sapropels, Site 974 to 977 and 979. In: Zahn, R., Comas, M.C. \& Klaus, A. (eds) Proceeding of the Ocean Drilling Program, Scientific Results, 161. Ocean Drilling Program, College Station, TX, 159-183.

Dettman, D.L., Reische, A.K. \& Lohman, K.C. 1999. Controls on the stable isotope composition of seasonal growth bands in aragonitic fresh-water bivalves (Unionidae). Geochimica et Cosmochimica Acta, 63, 1049-1057.

EPICA Community Members 2004. Eight glacial cycles from an Antarctic ice core. Nature, 429, 623-628.

FAO 2002. LocClim 1.0. SDRN Working Paper, 9.

Grossman, E.L. \& KU, T.-L. 1986. Oxygen and carbon isotope fractionation in biogenic aragonite: temperature effects. Chemical Geology, 59, 59-74.

Hanken, N.-M., Bromley, R.G. \& Miller, J. 1996. Plio-Pleistocene sedimentation in coastal grabens, north-east Rhodes, Greece. Geological Journal, 31, $271-296$.

Head, M.J. \& Gibbard, P.L. 2005. Early-Middle Pleistocene transitions: an overview and recommendation for the defining boundary. In: HEAD, M.J. \& GibBard, P.L. (eds) Early-Middle Pleistocene Transitions: The LandOcean Evidence. Geological Society, London, Special Publications, 247, $1-18$.

Heusser, L.E. \& Balsam, W.L. 1977. Pollen distribution in the Northeast Pacific Ocean. Quaternary Research, 7, 45-62.

Horowitz, A. 1989. Continuous pollen diagrams for the last 3.5 My. From Israel: vegetation, climate and correlation with the oxygen isotope record. Palaeogeography, Palaeoclimatology, Palaeoecology, 72, 63-78.

JoAnnin, S. 2007. Changements climatiques en méditerranée à la transition Pléistocène inférieur-moyen: pollens, isotopes stables et cyclostratigraphie. $\mathrm{PhD}$ thesis, University Lyon 1.

Kroon, D., Alexander, I., Little, M., Lourens, L.J., Matthewson, A.H.F. \& SAKAmoto, T. ET AL. 1998. Oxygen isotope and sapropel stratigraphy in the Eastern Mediterranean during the last 3.2 million years. In: ROBERTSON, A.H.F., Emeis, K.-C. \& Richter, C.et AL. (eds) Proceedings of the Ocean Drilling Program, Scientific Results, 160. Ocean Drilling Program, College Station, TX, 181-189.

Laskar, J., Robutel, P., Joutel, F., Gastineau, M., Correia, A.C.M. \& LEVRARD, B. 2004. A long-term numerical solution for the insolation quantities of the Earth. Astronomy and Astrophysics, 428, 261-285.

Levitus, 1994. World Ocean Atlas 1994, an atlas of objectively analyzed fields of major ocean parameters. World Wide Web Address: http://ingrid.ldeo. columbia.edu/SOURCES/.LEVITUS94/.

Lisiecki, L.E. \& RAYMo, M.E. 2005. A Pliocene-Pleistocene stack of 57 globally distributed benthic $\delta^{18} \mathrm{O}$ records. Paleoceanography, 20, 1-17.

Magri, D. \& Tzedakis, P.C. 2000. Orbital signatures and long-term vegetation patterns in the Mediterranean. Quaternary International, 73-74, 69-78.

Maslin, M.A. \& Ridgwell, A.J. 2005. Mid-Pleistocene Revolution and the 'eccentricity myth'. In: Head, M.J. \& GibBard, P.L. (eds) Early-Middle Pleistocene Transitions: the Land-Ocean Evidence. Geological Society, London, Special Publications, 247, 19-34.

McConnaughey, T.A., Burdett, J., Whelan, J.F. \& Paull, C.K. 1997. Carbon isotopes in biological carbonates: respiration and photosynthesis. Geochimica et Cosmochimica Acta, 61, 611-622.

Meulenkamp, J.E., De Mulder, E.F.J. \& Van De Weerd, A. 1972. Sedimentary history and paleogeography of the Late Cenozoic of the Island of Rhodos. Zeitschrift der Deutschen Geologischen Gesellschaft, 123, 541-553.

Mommersteeg, H.J.P.M., Loutre, M.F., Young, R., Wijmstra, T.A. \& HooGHiemstra, H. 1995. Orbital forced frequencies in the 975,000 year pollen record from Tenagi Philippon (Greece). Climate Dynamics, 11, 4-24.

Mudelsee, M. \& Stattegger, K. 1997. Exploring the structure of the midPleistocene revolution with advance methods of time-series analysis. Geologische Rundschau, 86, 499-511.

Mutti, E., Orombelli, G. \& Pozzi, R. 1970. Geological studies on the Dodecanese Islands (Aegean Sea): IX. Geological map of the island of Rhodes (Greece); explanatory notes. Annales Géologiques des Pays Helléniques, 22, 79-226.

Okuda, M., Van Vugt, N., Nakagawa, T., Ikeya, M., Hayashida, A., Yasuda, Y. \& Setoguchi, T. 2002. Palynological evidence for the astronomical origin of lignite-detritus sequence in the Middle Pleistocene Marathousa Member, Megalopolis, SW Greece. Earth and Planetary Science Letters, 201, $143-157$.

Ozenda, P. 1975. Sur les étages de végétation dans les montagnes du bassin méditerranéen. Documents de Cartographie Ecologique, 16, 1-32.

PIERRE, C. 1999. The oxygen and carbon isotope distribution in the Mediterranean water masses. Marine Geology, 153, 41-55.

Pisias, N.G. \& Moore, T.C. 1981. The evolution of Pleistocene climate: A time series approach. Earth and Planetary Science Letters, 52, 450-458.

Quézel, P. 1998. Cèdres et cédraies du pourtour méditerranéen: signification bioclimatique et phytogéographique. Forêt Méditerranéenne, XIX, 234-260.

Quézel, P. \& BARbero, M. 1985. Carte de la végétation potentielle de la région 
méditerranéenne. Feuille No. 1: Méditerranée orientale. Centre National de la Recherche Scientifique, Paris, 1.

QuÉzel, P. \& Médail, F. 2003. Ecologie et Biogéographie des Forêts du Basin Méditerranéen. Elsevier, Amsterdam.

RAFFI, S. 1986. The significance of marine boreal molluscs in the Early Pleistocene faunas of the Mediterranean area. Palaeogeography, Palaeoclimatology, Palaeoecology, 52, 267-289.

Ravazzi, C. \& Rossignol-Strick, M. 1995. Vegetation change in a climatic cycle of early Pleistocene age in the Leffe Basin (Northern Italy). Palaeogeography, Palaeoclimatology, Palaeoecology, 117, 105-122.

Ravazzi, C., Pini, R. \& Breda, M. ET AL. 2005. The lacustrine deposits of Fornaci di Ranica (late Early Pleistocene, Italian Pre-Alps): stratigraphy, palaeoenvironment and geological evolution. Quaternary International, 131, 35-58.

Rossignol-Strick, M. \& Paterne, M. 1999. A synthetic pollen record of the eastern Mediterranean sapropels of the last $1 \mathrm{Ma}$ : implications for the timescale and formation of sapropels. Marine Geology, 153, 221-237.

RudDiman, W.F. 2003. Orbital forcing ice volume and greenhouse gases. Quaternary Science Reviews, 22, 1597-1629.

Russo ERmolli, E. 1994. Analyse pollinique de la succession lacustre Pléistocène du Vallo di Diano (Campanie, Italie). Annales de la Société Géologique de Belgique, 117, 333-354.

Russo ERmolli, E. 1999. Vegetation dynamics and climate changes at Camerota (Campania, Italy) at the Pliocene-Pleistocene boundary. Il Quaternario, 12, 207-214.

Shackleton, N.J., Crowhurst, S., Weedon, G. \& Laskar, J. 1999. Astronomical calibration of Oligocene-Miocene time. Proceedings of the Royal Society of London, Series A, 357, 1907-1929.

STIROS, S.C. 1998. Archaeological evidence for unusually rapid Holocene uplift rates in an active normal faulting terrain: Roman harbour of Aigeira, Gulf of Corinth, Greece. Geoarchaeology, 13, 731-741.

Subally, D. \& Quézel, P. 2002. Glacial or interglacial: Artemisia, a plant indicator with dual responses. Review of Palaeobotany and Palynology, 120, $123-130$.

Subally, D., Bilodeau, G., Tamrat, E., Ferry, S., Debard, E. \& HillaireMARCEL, C. 1999. Cyclic climatic records during the Olduvai Subchron
(Uppermost Pliocene) on Zakynthos Island (Ionian Sea). Geobios, 32, 793-803. Suc, J.-P. 1984. Origin and evolution of the Mediterranean vegetation and climate in Europe. Nature, 307, 429-432.

Suc, J.-P. \& Popescu, S.-M. 2005. Pollen records and climatic cycles in the North Mediterranean region since $2.7 \mathrm{Ma}$. In: HEAD, M.J. \& GibBard, P.L. (eds) Early-Middle Pleistocene Transitions: The Land-Ocean Evidence. Geological Society, London, Special Publications, 247, 147-157.

Suc, J.-P. \& ZAGWIJN, W.H. 1983. Plio-Pleistocene correlations between the northwestern Mediterranean region and northwestern Europe according to recent biostratigraphic and paleoclimatic data. Boreas, 12, 153-166.

Svenning, J.-C. 2003. Deterministic Plio-Pleistocene extinctions in the European cool-temperate tree flora. Ecology Letters, 6, 646-653.

TAYLOR, B.E. \& WARD, P.D. 1983. Stable isotopic studies of Nautilus macromphalus Sowerby (New Caledonia) and Nautilus pompilius L (Fiji). Palaeogeography, Palaeoclimatology, Palaeoecology, 41, 1-16.

Ten Veen, J.H. \& Kleinspehn, K.L. 2002. Geodynamics along an increasingly curved convergent plate margin: Late Miocene-Pleistocene Rhodes, Greece. Tectonics, 21, 1-21.

Tzedakis, P.C., McManus, J.F., Hooghiemstra, H., Oppo, D.W. \& Wijmstra, T.A. 2003. Comparison of changes in vegetation in northeast Greece with records of climate variability on orbital and suborbital frequencies over the last 450000 years. Earth and Planetary Science Letters, 212, 197-212.

VANNEY, J.-R. \& GenNESEAUX, M. 1985. Mediterranean seafloor features: overview and assesment. In: Stanley, D.J. \& WetZal, F.-C. (eds) Geological Evolution of the Mediterranean Basin. Springer, New York, $3-32$.

Von Grafenstein, R., Zahn, R., Tiedemann, R. \& Murat, A. 1999. Planktonic $\delta^{18} \mathrm{O}$ records at sites 976 and 977 , Alboran Sea: stratigraphy, forcing, and paleoceanographic implications. In: ZaHn, R., Comas, M.C. \& Klaus, A. (eds) Proceeding of the Ocean Drilling Program, Scientific Results, 161. Ocean Drilling Program, College Station, TX, 469-479.

Wijmstra, T.A. \& SMit, A. 1976. Palynology of the middle part (30-78 metres) of the $120 \mathrm{~m}$ deep section in northern Greece (Macedonia). Acta Botanica Neerlandica, 25, 297-312.

Woodside, J., Mascle, J., Huguen, C. \& Volkonskaia, A. 2000. The Rhodes basin, a post-Miocene tectonic trough. Marine Geology, 165, 1-12.

Received 8 June 2006; revised typescript accepted 4 May 2007. Scientific editing by Jamie Woodward 